\title{
Stages for Introduction of Drawing Actions in Pre-School Age
}

\author{
Yulia Solovieva $^{1 *} \&$ Luis Quintanar ${ }^{1}$ \\ ${ }^{1}$ Faculty of Psychology, Autonomous University of Puebla, Mexico \\ *Yulia Solovieva, E-mail: yulia.solovieva@correo.buap.mx \\ Received: March 22, 2017 \\ Accepted: March 31, 2017 \\ Online Published: April 8, 2017 \\ doi:10.22158/jecs.v1n1p12 \\ URL: http://dx.doi.org/10.22158/jecs.v1n1p12
}

\begin{abstract}
The process of learning and achievements at school depends on the types of activities selected at pre-school level. Unfortunately, it is often to find out that introduction of writing and reading is among the most common activities in pre-school institutions all over the world. According to historical and cultural conception of development, artistic and creative activities are useful and helpful at pre-school age. The goal of the article is to show the efficiency of original program for initial introduction of drawing actions at pre-school age. The original program for gradual formation of drawing by stages was applied in private college in Puebla (Mexico). The program included three stages and worked as joint activities in groups of pre-scholars of three grades. After program application children showed qualitative positive achievements in graphic representations of objects, spatial orientation, number of drawings and of essential features of represented real and imaginary objects and situations. We conclude that drawing is extremely useful activity for preparation for school and introducing space orientation on perceptive level. Our program may be used in pre-school institutions in order to guarantee required level psychological development at pre-school age.
\end{abstract}

\section{Keywords}

drawing, formation of drawing, preschool development, spatial development

\section{Introduction}

Pre-school age is considered as the period of grate importance for the child's psychological development and for preparation for school (Salmina, 2010; Obukhova, 2006). The process of learning at school depends on the organization and selection of activities, in which the child takes part during this period of development. Pre-school institutions frequently chose tasks and activities empirically without any justification from psychological point of view.

According to historical and cultural conception of psychological development, introduced by Vigotsky (2001), pre-school age is a sensitive period for acquisition of personality, during which broad variety of communicative and creative activities might be very useful. Vigotsky himself created circles for reading and performance of plays with young children. The art, as an integrate part of general cultural 
experience, is one of the goal of psychological development of a human being (Vigotsky, 2001). The communication with art becomes accessible and significant at pre-school age. In that sense, different kinds of artistic activities and communicative activities are favourable for pre-scholars. The followers of Vigotsky's conception of psychological development have developed the theory of periodization of psychological development with detailed concepts of content and structure of psychological age (Elkonin, 1989). Within this theory, play with social roles as a rector activity of pre-school age is one of central aspects (Elkonin, 1989; Solovieva \& Quintanar, 2012a). Grate importance is given to symbolic development at pre-school age, which in considered as one of central psychological formations of pre-school age. Our own studies were dedicated to discovery of possibilities of gradual formation of symbolic function within play with social roles activity (Solovieva, Gonzáles, \& Quintanar, 2016; Solovieva \& Gonzáles, 2016). Verbal development and formation of broad circle of communicative and representative means of expression is another fundamental aspect of pre-school age (Solovieva, López, \& Quintanar, 2015). Regulative function of own speech, before passing on the level of inner speech, according to Vigotsky (1995a) might be acquired gradually by specific work and strategies within preschool institutions (Solovieva, López, \& Quintanar, 2015).

According to modern neuropsychological research, there is another important aspect of psychological development, which wasn't taken into account seriously. This aspect refers to spatial orientation as fundamental functional mechanism. Research has detected that difficulties in school learning at primary school might be related to poor level of acquisition of spatial functions (Akhutina \& Zolotariova, 2007; Solovieva \& Quintanar, 2016b). Spatial functions include global strategy of perception representations as unique images and analytic strategy of perception of details and coordinates orientation.

Different studies have detected impropriate development of concrete visual images at the end of pre-school age (Akhutina \& Pilayeva, 2003; Veraksa, N. E. \& Veraksa, A. N., 2012). Poor level of development of images of perception may conduct to spatial confusion of letters, mathematic signs and digits at school. Problems with spatial orientation may become a cause of difficulties in written production and understanding of texts together with impossibility to interiorize structure of number and to solve properly mathematic problems (Akhutina \& Zolotariova, 2007). It is possible to say that luck of development of spatial orientation is one of the reasons why many children receive diagnosis of dyslexia, dysgraphia and dyscalculia (Akhutina \& Zolotariova, 2007; Akhutina \& Inshakova, 2008; Akhutina \& Pilayeva, 2012).

Prevention of difficulties in future school learning has become in a topic of attention of developmental psychologists and neuropsychologists (Solovieva \& Quintanar, 2014, 2016a). Creation and introduction of new methods for psychological development might show new paths for early education. Our proposal consists in initial introduction of joint actions of drawing from the very beginning (Solovieva \& Quintanar, 2016b).

The objective of our study is to show the possibility of introduction of drawing action as a strategy for development of spatial orientation in pre-school age. Our method is also important for general 
psychological development and for training of visual and spatial functions at pre-school and might be implemented in groups of children who assist educational institutions.

\section{Method}

The method of the study is qualitative psychological and pedagogical experiment consisting in working with original program for gradual formation of drawing activity. Such formation qualitative experiment belongs to Vigotsky's and Gaperin's tradition, when the process of experiment is dedicated to gradual formation (Galperin, 2002).

The program for stage-by-stage formation of actions of drawing was created for such a purpose. The program has being applied in private Kinder Garden during three years in three grades of formal pre-school educational level. Groups of children from 3 to 4 ; from 4 to 5 and from 5 to 6 years old were included en sequential levels of the Program during three years. The number of children varied from 6 to 10 participants in groups per school year. This variation is due to different natural reasons.

Pedagogical work was carried out by pre-school teachers of the College under constant orientation provided by the authors of the method and expert in cultural psychological development.

The program is based on the following theoretical and methodological psychological conceptions:

Cultural-historic paradigm of psychological development (Vigotsky, 1995a; Leontiev, 2000).

Theory of step-by-step formation of mental actions (Talizina, 2009; Galperin, 2000).

Orientation base of action during the introduction of new actions (Zaporozhets, 2000; Solovieva, 2014).

The zone of proximate development applied during elaboration of orientation base of action (Solovieva, 2014; Solovieva \& Quintanar, 2016a).

According to activity theory proposal, each kind of activity might be analysed according to it's psychological structure and content (Leontiev, 1983). It is possible to identify necessity, motive, objective, object, orientation, operations and means and result in each kind of activity. The program for gradual introduction of drawing takes into account psychological structure of actions of drawing. The elements of this structure are the following:

Necessity: social necessity of communication.

Motive: representation of objects, cognitive broad motivation and formation of aesthetic motivation.

Objective: gradual reflection of the objective for representation of objects and features, real and imaginary situations.

Object: visual perceptive image of objects.

Orientation: introduced and shared by constant participation of pedagogue, analysis of features of the objects and external presentation of shapes of the objects.

Operations and means: usage of pencil, colours, paper, shapes and details of real objects, different graphic means.

Result: drawing produced by each child as a result of joint work in groups.

The practical work with the children starts from external level and later on passes up to internal Published by SCHOLINK INC. 
perceptive level. All tasks are introduced as collective shared and communicative actions between children and teacher:

Election of the object, which will be drawn.

Organization of the space of the sheet of paper for representation of the shape and of elements of the object.

Determination of the general predominate shape of the object.

Election and disposition of the details of the objects.

Representation of the shape of object with the help of external shape.

Representation of specific details of the object.

Verification of the whole execution, comparison with the model, detection of errors, correction of errors.

The program includes three general stages:

1) Previous stage (preparation of drawing), 2) drawing of independent objects according to the shape and external model, 3) drawing of objects which enriched features according to internal model, drawing of situations ("illustrations for fairy tails") according to external and later to internal model.

The stage 1 was used for the first grade of pre-school education; stage 2 for the second grade and the stage 3 for the third grade. The Tables 1, 2 and 3 present respectively the content of actions used on stages 1,2 and 3 .

Table 1. Contents of Actions on the First Stage

First stage
Preparation of drawing
External material actions
Denomination of objects.
$\begin{aligned} & \text { Identification of all kinds of features in real } \\ & \text { objects. }\end{aligned}$
objects.

Comparison of real objects by the same features. Work with different and similar features of real objects.

Identification of similarity in one feature and differences in another feature.

Identification of the shape of objects.

Comparison and classification of objects according to the shape.

Identification of spatial characteristics of objects and all details of the objects.

Comparison of objects according to spatial distribution of its details.

Comparison of perceptive representations of objects according to diverse features stressing the
Content and examples of activities

Different kinds of toys, objects, animals, instruments which are new and interesting for children.

Color, shape, spatial orientation, transparent, solid, liquid, big, fat, tall, thin, all kinds of synonyms and antonyms can be used.

Comparison of all kinds of features in real objects. Shape is used and stressed as one of essential feature of the object. Demonstration of multiple options for differentiation and for identification of similarity in real objects.

Usage of external shapes, made of paper or plastic $5 \times 5 \mathrm{~cm}$ (square, circle, triangle, rectangle, oval, star, heart and so on). See example 3.

Constant usage of external shapes.

High-low, close-opened, up-down, close-far, left-right, inside-outside, etc.

On the left-on the right, closer-further, etc.

Pictures, photos, drawings, illustrations, postcards, representations and so on. See examples 4 and 5 . 
shape as one of the most important.

Symbolic representation of actions with objects and gestures (using hands movement similar to horizontal and vertical line).

Symbolic representation of lines on the paper. Usage of vertical and horizontal lines (movement of the pencil) in relation to imaginary symbolic actions.

Symbolic representation of shapes. Imaginary analysis of shapes of objects. Proposal an object and its relation to the shape. It in necessary to stress that one object can be represented by different shapes: table can be round or square or triangle, and so on.
How to clean the table, how to paint the wall, how to close the door, how to open the window, how to cut the bread, how to open the curtain, etc.

Same actions as in previous stage and all kind of natural phenomenon: the rain, the rainbow, the sun shining, snow, water, sea, stars, sand, grass, and so on.

Constant drawing of different shapes on the blackboard, on the sand, in space, on the shoulder of a friend, etc. Mentioning of all kinds of objects which could be related to this shapes.

Constant usage of external shapes while drawing.

Table 2. Contents of Actions on the Second Stage

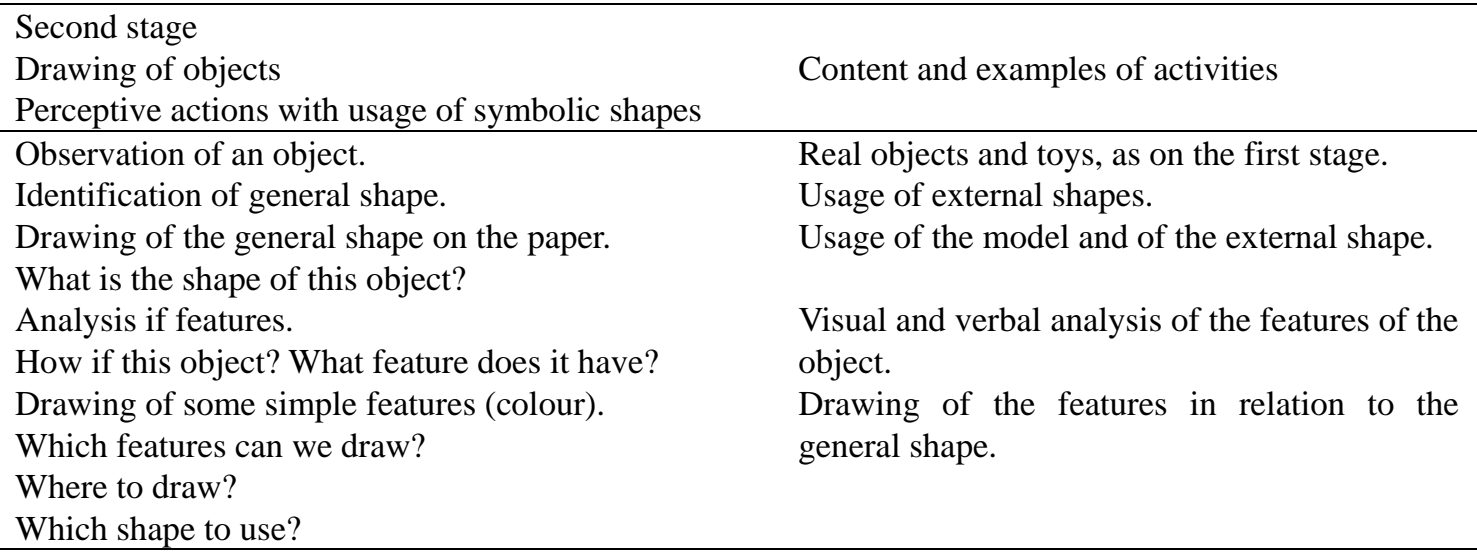

Table 3. Contents of Actions on the Third Stage

\begin{tabular}{|c|c|}
\hline $\begin{array}{l}\text { Third stage } \\
\text { Drawing of objects } \\
\text { Independent perceptive actions with usage of } \\
\text { internal representation of shapes. Imagination of } \\
\text { models }\end{array}$ & Content and examples of activities \\
\hline $\begin{array}{l}\text { Imagination of an object or situation: } \\
\text { Identification of details, shapes, colours. }\end{array}$ & $\begin{array}{l}\text { Telling stories or imaginary situations, dialogues } \\
\text { in groups. } \\
\text { Conversations or listening of stories. }\end{array}$ \\
\hline $\begin{array}{l}\text { Drawing of the general shape on the paper: } \\
\text { What is the shape of this object? }\end{array}$ & $\begin{array}{l}\text { Collective analysis of details of representations or } \\
\text { possibilities. }\end{array}$ \\
\hline Comparison of drawings: & Visual and verbal analysis of produced drawings. \\
\hline
\end{tabular}

How if this object? What feature does it have?

Complete independent drawing:

What do you want to draw?

Oral complementary orientation and discussions on the topics of drawings.

Which features shall we draw and how?

Where to draw? 


\section{Examples}

Examples of drawing produced by children of 3-5 years old are presented below (1st, 2nd and 3rd grades of preschool educational). Children were included in the program starting from 3 year old and continued to work with the program during 3 years for 3 hours per week in regular groups of preschool education.

Stage 1. 3-4 years old.
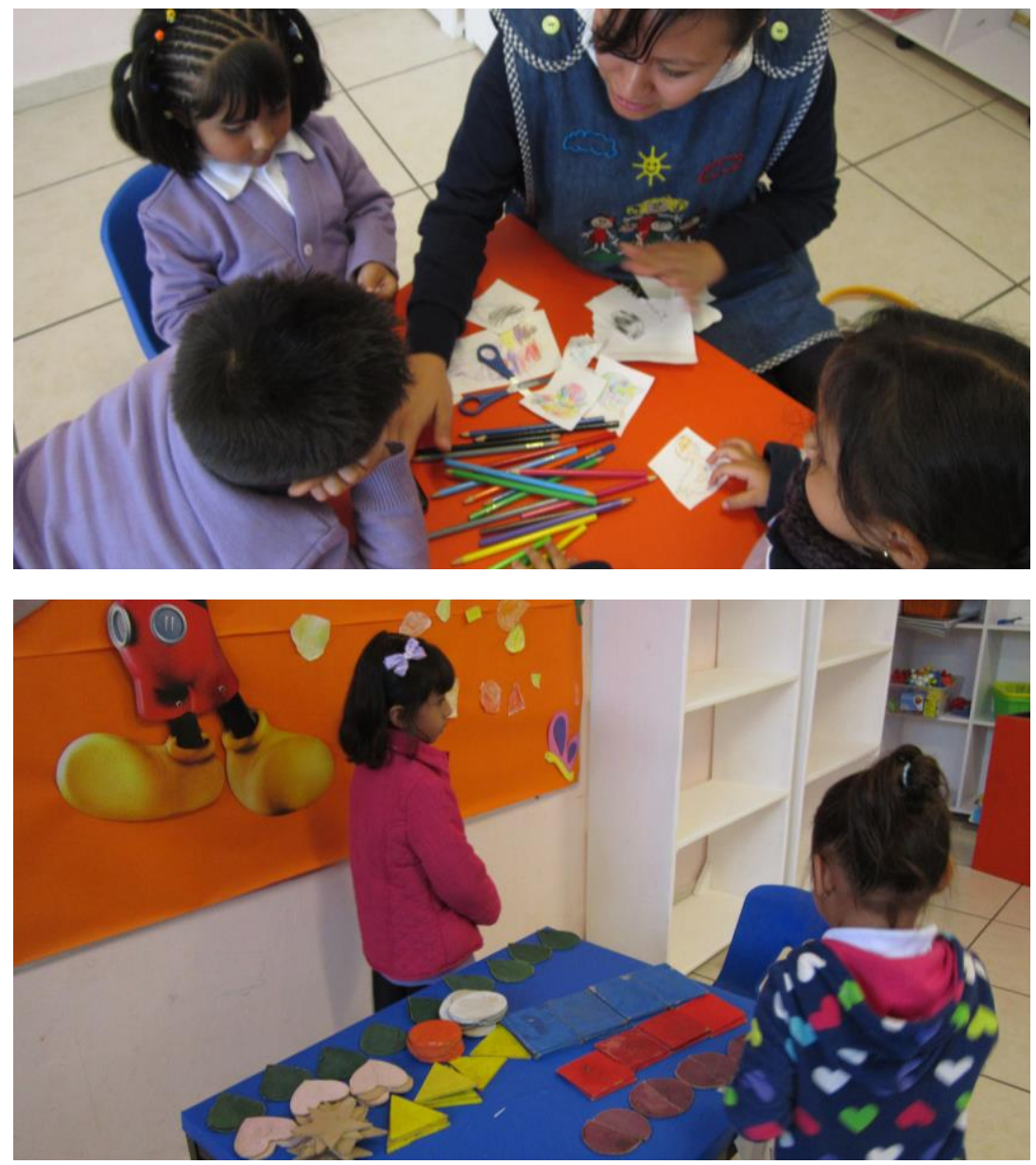

Figures 1-2. Working with External Shapes and Gestures

Stage 1. 3-4 years old. 

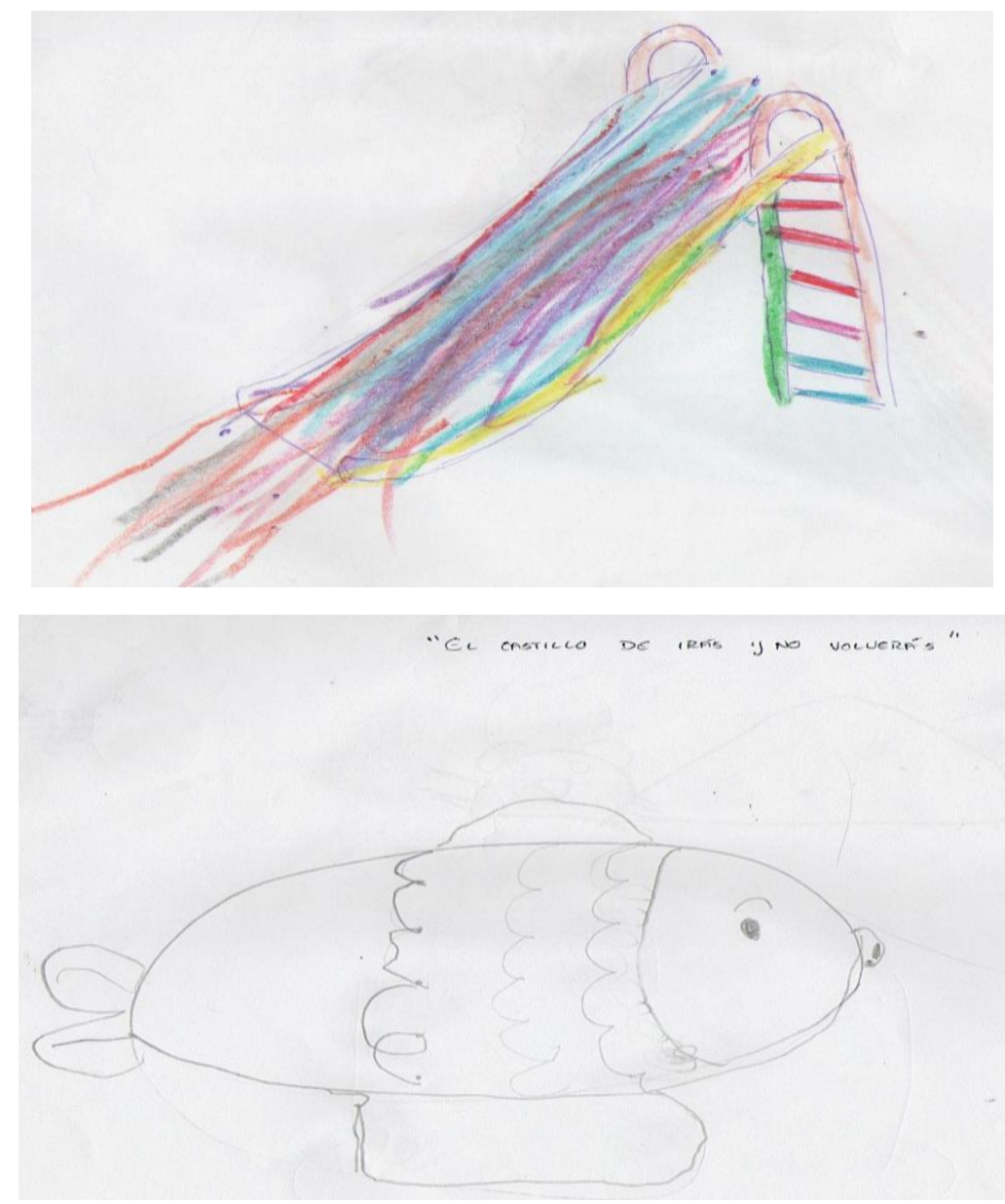

Figures 3-4. Working with External Gestures and Drawing of Lines and Shapes of Simple Objects

Stage 2. 4-5 years old.

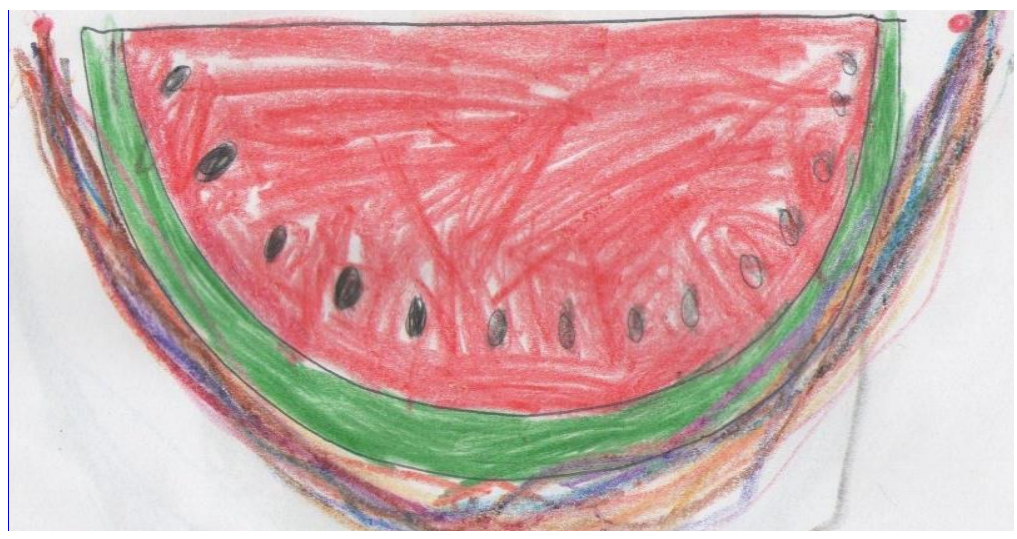




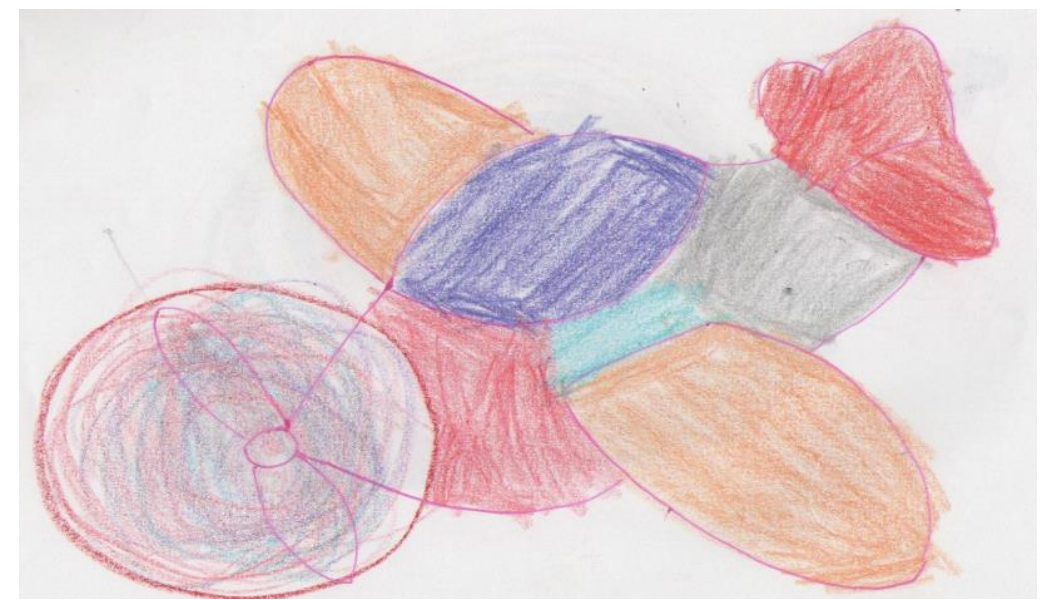

Figures 5-6. Drawing of Object Based on Perception and Generalization of Shapes of Models

Stage 3. 5-6 years old.
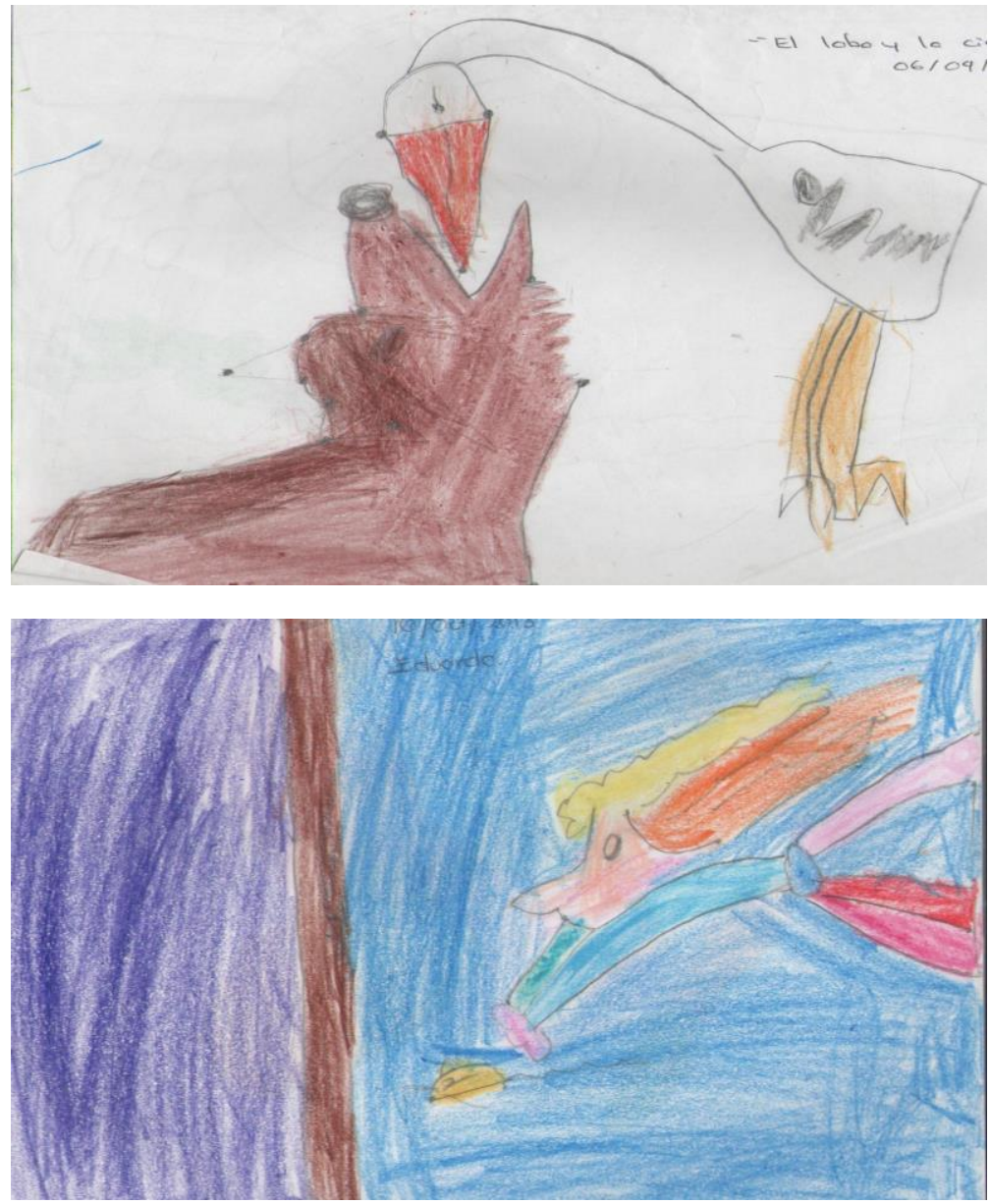

Figures 7-8. Drawing of Objects Based on Internal Shapes Perception and Imaginative Models 


\section{Discussion}

Presented examples show how children modify and develop their abilities of representation of the objects from one stage to another. They have started with elemental representation of gestures and actions. Afterwards, they were able to draw only lines and shapes. Next, ability for drawing of complex objects appeared. Finally, little children were able to draw imaginative creative images.

Our work permits to understand that cultural activities, as drawing of objects, do not appear "naturally" or as a kind of "metacognitive ability". The only real possibility of formation of drawing is participation in activities of drawing, but starting from the level accessible for children. We have shown that this possible starting from three years old in regular Mexican children. We are convinced that similar results might be obtained in other cultures and communities and the only thing to do is to start using our program creatively, showing love and understanding to children.

Normally, the level of acquisition of graphic abilities is very low before entering the school in Mexican children. As one of the consequence, strong difficulties in writing related to visual and spatial functions appear in primary school. Common methods related to usage of drawing only provide few lessons or sessions without any specific orientation and do not consider psychological structure of graphic activity (Venguer, 2002). Perceptive difficulties and errors in graphic representation are always been described as "normal stages of development".

Different psychologists starting with Vigotsky himself have claimed for argumentation of significance of drawing and other kind of artistic activities for young children (Vigotsky, 1995b). Traditional understanding of Vigotsky's conception of the zone of proximate development works doesn't include the concept of orientation of action. On the contrary, profound theoretical understanding together with practical implementation of Galperin's theory of orientation base of action (Galperin, 1998), have permitted to the author the creation of the program for introduction of drawing activity by stages.

The first stage, as it was shown in the article, pretends to expand simple perception of objects as syncretic images into reflexive identification of essential features. This kind of reflexive recognition of features of the objects includes the possibility of generalization of shapes of objects. Generalization of the shapes permits to start with imagination and complex variation of the usage of the shapes. The shape is the essential feature of the objects, which able the child to imagine, generalize and represent an object on the graphic level. The generalization of the shape helps the child to draw appropriate lines on the paper in order to represent the necessary object.

Later on, the children start to analyse the objects and simple common situations by themselves. All our children talk always loudly in groups, touch the toys and objects, smile to the teacher and constantly ask questions about the features of objects and situations.

On the last stage of drawing of complex imaginary situations, as our examples show, children could were able to draw not only isolated objects, but diverse groups of objects related to the common situations. The drawing reflected the contents of fairy tails and stories, which children heard from the teacher in groups. Our method never combines reading of stories with drawing at the same session, 
because each activity needs special orientation. The contents of fairy tails of reading sessions are later used during drawing sessions. Such strategy permits children to remember better the content of the tails and imagine all real and supposed (imagined) details and features of the stories (Solovieva \& Quintanar, 2016a).

The program shows that initial level of orientation with material and materialized actions is the source for all next stages of graphic activity (Solovieva, 2014). In order to form drawing as reflexive activity, it would be not useful to start with drawing by itself, but with different kinds of intellectual actions of comparison with objects and toys. Same situation happens with writing at school. Be are sure that the drawing is useful as the stage of preparation of writing process and the it would be not useful to introduce writing starting with writing itself.

Important psychological recommendation to all kinder gardens would, according to our article, not to work with writing but with drawing. The drawing might be introduced starting with three years old with normal children or children without learning disabilities. The topic of introduction of drawing in cases of learning and developmental disabilities is the question of child neuropsychology and developmental psychology (Solovieva \& Quintanar, 2015, 2016c).

Only after working systematically, day by day, in groups of children, it would be possible to achieve high drawing ability. Isolated tasks or sporadic work would never permit to achieve same goals. According to our previous experience, starting with older children requires to start with the same stage and not with the last stage of our proposal (Solovieva \& Quintanar, 2012b). In the case of older children, of the age of 5 to 6 years, positive results might be achieved, but the level of drawings would never be the same as starting from the age of three year and working for three years of pre-school education.

Our method shows the possibility of cultural development, which bases on special created orientation provided by an adult during joint interaction. We are sure that this kind of understanding of historical and cultural conception of development is a productive way of using of Vigotsky's theory in practice of developmental and educational psychology. Concepts of activity theory such as motive, orientation and guidance help to enrich Vigotsky's initial understanding of the zone of proximate development. The zone of proximate development need to be transformed to the level of possible practice application according to detailed analysis of the structure and content of the actions used in joint activity by adult and child. Such specific detailed elaborationof the kind of orientation differ from the common opinion of simple social interaction in groups of children without any kind of guidance or orientation proposed by adults. Such interpretation of Vigotsky's theory is only one of possible interpretations. Our interpretation follows Leontiev's activity theory, which consider formation of psychological activities as process based on own reflexion, orientation and conscious understanding of objective and means of actions (Leontiev, 2000).

Implementation of drawing activity is definitely based of psychological conception of cultural age (Elkonin, 1989; Obukhova, 2006; Solovieva \& Quintanar, 2012a). Pre-school age is the age of playing 
activity, imagination, artistic development and introduction of communicative verbal and non-verbal abilities (Vigotsky, 2001). Conceptual age of systematic learning should be introduced later and only on the basis of profoundly achieved level of social communication, imagination voluntary activity (Mújina, 1990; Talizina, 2009). Drawing and graphic representation should be added to this important list of new psychological formations of preschool age.

According to historical and cultural conception of psychological development and activity theory, it is possible to introduce and to guide the children in their activities. In our research, we propose to start on material level of concrete objects so that the child could feel and appreciate al features of the objects. After that we pass to perceptive level when we work with lines and images. The materialized orientation is presented all the time on order to facilitate identification of shapes in real and perceptive objects (Salmina \& Glebova, 2005a, 2005b, 2009). The introduction of graphic activity is based on initial usage of gestures, actions and external shapes of objects (Solovieva \& Quintanar, 2012b, 2013, 2016b).

Before the program all children have shown absence of developed drawing activity. After program application all children showed qualitative positive achievements in graphic activity such as spatial global and analytic orientation, essential features and shapes of represented objects. The authors are convinced that, together with play with social roles, formation of drawing might become one of essential kinds of the methods for psychological development at pre-school age.

We are convinced that our program may be used in pre-school institutions in order to guarantee correspondent level or preparation for school learning. Our proposal offers a possibility for real practical application of the zone of proximate development in specific case of introduction of graphic activity in groups at pre-school age. Other kind of activities would require of elaboration and realization of specific orientations based on the analyses of structure and content of each activity (Gaplerin, 1998; Talizina, 2009; Solovieva, 2016).

The authors hope that their proposal will be interesting and helpful for specialists worried about efficiency of the methods of pre-school education.

\section{Conclusions}

The drawing activity is an example of meaningful cultural activity, which might be introduced from the very elementary level in infancy. Young children, starting with three years old are capable to take part in activities in groups and be guided by an adult in specific direction.

Pre-school age represents specific period of psychological development, when children may be involved in artistic activities. Orientation is the main element of each kind of activity and it's usage might become an important psychological instrument of development.

Our results show importance of drawing and its implementation by stages in pre-school institutions. 


\section{References}

Akhutina, T. V., \& Inshakova, O. B. (2008). Diagnóstico y evaluación neuropsicológica de la escritura y lectura en los escolares menores. Moscú: Centro creativo V. Sekachev.

Akhutina, T. V., \& Pilayeva, N. M. (2003). Diagnóstico y desarrollo de las funciones visuo-verbales. Moscú: Academia.

Akhutina, T. V., \& Pilayeva, N. M. (2012). Overcoming learning disabilities. A Vigotskian-Lurian neuropsychological approach. Cambridge: Cambridge University Press. https://doi.org/10.1017/CBO9781139012799

Akhutina, T. V., \& Zolotariova, E. V. (2007). Acerca de la disgrafia visuo-espacial: Análisis neuropsicológico y métodos de corrección. In L. Quintanar, \& Y. Solovieva (Eds.), Métodos de intervención en la neuropsicológica infantil (pp. 39-46). México: Universidad Autónoma de Puebla.

Elkonin, D. B. (1989). Obras psicológicas escogidas. Moscú: Pedagogía.

Galperin, P. Y. (1998). Actividad psicológica como ciencia objetiva. Moscú: Instituto de Ciencias Pedagógicas y Sociales.

Galperin, P. Y. (2000). Psicología: Cuatro conferencias. Moscú: Escuela Superior.

Galperin, P. Y. (2002). Introducción a la psicología. Moscú: Escuela Superior.

Leontiev, A. N. (1975). Actividad, conciencia, personalidad. Moscú, Universidad Estatal de Moscú.

Leontiev, A. N. (1983). Obras escogidas. Moscú, Universidad Estatal de Moscú.

Leontiev, A. N. (2000). Conferencias sobre psicología general. Moscú, Sentido.

Mújina, V. M. (1990). Psicología de la edad preescolar. Madrid: Visor.

Obukhova L. F. (2006). Psicología del desarrollo. Moscú: Educación superior.

Salmina, N. G. (2009). Aprendemos a pensar. Parte I y II. Moscú: Ventana-Graf.

Salmina, N. G. (2010). Indicadores de la preparación de los niños para la escuela. In Y. Solovieva, \& L. Quintanar (Eds.), Antología del desarrollo psicológico del niño en la edad preescolar (pp. 67-74). México: Trillas.

Salmina, N. G., \& Glebova, A. O. (2005a). Aprendemos a dibujar. Análisis de formas y creación de la imagen. Moscú: Ventana-Graf.

Salmina, N. G., \& Glebova, A. O. (2005b). Aprendemos a dibujar. Líneas y rayas. Moscú: Ventana-Graf.

Solovieva, Y. (2014). La actividad intelectual en el paradigma histórico-cultural. México: CEIDE.

Solovieva, Y., \& Gonzáles, C. (2016). Indicadores de la adquisición de la función simbólica en el nivel de acciones verbales en preescolares. Revista de la Facultad de Medicina, 64(2), 257-265. https://doi.org/10.15446/revfacmed.v64n2.52995

Solovieva, Y., \& Quintanar, L. (2012a). Actividad de juego en la edad preescolar. México: Trillas.

Solovieva, Y., \& Quintanar, L. (2012b). Formation of drawing activity in Mexican preschool children. Psychology Research, 2(8), 479-489. 
Solovieva, Y., \& Quintanar, L. (2013). Importance of drawing development in preschool age. Preschool Education Today, 1, 80-84.

Solovieva, Y., \& Quintanar, L. (2014). Enseñanza de la lectura. Un método práctico. México: Trillas.

Solovieva, Y., \& Quintanar, L. (2015). Games as a Method of Correction in Prescool Mexican Children with ADDH. British Journal of Education, Society \& Behavioural Science, 11(3), 1-14. https://doi.org/10.9734/BJESBS/2015/19124

Solovieva, Y., \& Quintanar, L. (2016c). Educación neuropsicológica infantil. México, Trillas.

Solovieva, Y., \& Quintanar, L. (2016a). El dibujo como actividad formativa en la edad preescolar. México: Trillas.

Solovieva, Y., \& Quintanar, L. (2016b). The role of zone of proximate development in interactive assessment of intelectual development. British Journal of Education, Society \& Behavioural Science, 14(1), 1-11.

Solovieva, Y., Gonzáles, C., \& Quintanar, L. (2016). Developmental analysis of symbolic perceptual actions in preschools. British Journal of Education, Society \& Behavioural Science, 15(3), 1-13. https://doi.org/10.9734/BJESBS/2016/24459

Solovieva, Y., López, A., \& Quintanar, L. (2015). Formación de la función mediatizadora del lenguaje a través del análisis de cuentos en preescolares. Revista Educacao em Questao, 52(38), 11-35.

Talizina, N. F. (2009). La teoría de la actividad aplicada a la enseñanza. México: Universidad Autónoma de Puebla.

Venguer, A. L. (2002). Dibujos como pruebas psicológicas. Moscú: Vlados Press.

Veraksa, N. E., \& Veraksa, A. N. (2012). Desarrollo cognitivo en la edad preescolar. Moscú: Educación Profesional Superior.

Vigotsky, L. S. (1995a). Desarrollo del lenguaje oral. Obras escogidas. Tomo 3 (pp. 169-182). Madrid: Visor.

Vigotsky, L. S. (1995b). La prehistoria del desarrollo del lenguaje escrito. Obras escogidas. Tomo 3 (pp. 183-206). Madrid: Visor.

Vigotsky, L. S. (2001). La imaginación y el arte en la infancia. México: Ediciones Coyoacán. Psicología.

Zaporozhets, A. V. (2000). Psicología de la acción. Moscú: Academia de Ciencias Pedagógicas y Sociales. 